\title{
Reversal of Phencyclidine-Induced Dopaminergic Dysregulation by N-Methyl-D-Aspartate Receptor/Glycine-site Agonists
}

\author{
Daniel C Javitt*', Andrea Balla', Sarah Burch', Ray Suckow', Shan Xie' and Henry Sershen' \\ 'Nathan Kline Institute for Psychiatric Research, NYU School of Medicine, Orangeburg, NY, USA
}

\begin{abstract}
N-methyl-D-aspartate (NMDA) receptors may play a critical role in the pathophysiology of schizophrenia. In rodents, NMDA receptor antagonists, such as phencyclidine (PCP), induce dopaminergic dysregulation that resembles the pattern observed in schizophrenia. The present study investigates the degree to which concurrent treatment with NMDA modulators, such as glycine and the recently developed glycine transport antagonist N[3-(4"-fluorophenyl)-3-(4"-phenylphenoxy)propyl]sarcosine (NFPS) prevents dopaminergic dysregulation observed following chronic (3 months) or subchronic (2 weeks) PCP administration. Both chronic and subchronic treatment with PCP in the absence of glycine or NFPS led to significant potentiation of amphetamine-induced dopamine release in the prefrontal cortex and striatum, similar to that observed in schizophrenia. Treatment with either high-dose glycine or NFPS along with PCP prevented PCP effects. These findings demonstrate effective doses of glycine for use in animal models of schizophrenia, and support recent clinical studies showing the effectiveness of NMDA agonists in the treatment of persistent symptoms of schizophrenia. Neuropsychopharmacology (2004) 29, 300-307, advance online publication, I 5 October 2003; doi: I 0. I038/sj.npp. I 3003। 3
\end{abstract}

Keywords: glutamate; glycine; NMDA receptor; amphetamine; phencyclidine; schizoprenia

\section{INTRODUCTION}

Symptoms of schizophrenia have traditionally been attributed to the hyperactivity of brain dopaminergic systems (eg Davis et al, 1991; Moore et al, 1999). Over the past decade, however, the phencyclidine (PCP) model of schizophrenia has attained increasing prominence (Coyle, 1996; Javitt et al, 1987; Javitt and Zukin, 1990, 1991; Jentsch et al, 1999; Krystal et al, 1994; Newcomer et al, 1999). This model is based upon the observation that PCP and related agents such as ketamine induce schizophrenia-like symptoms by blocking $N$-methyl-D-aspartate (NMDA)-type glutamate receptors, and exacerbate symptoms in remitted patients. Further, agents that potentiate NMDA receptor-mediated neurotransmission significantly reduce persistent negative and cognitive symptoms of schizophrenia (Goff et al, 1999; Heresco-Levy et al, 1999; Javitt et al, 2001, 1994; Shoham et al, 2001; Tsai et al, 1998). Psychotomimetic effects of PCP are observed during both acute and chronic administration.

*Correspondence: Dr DC Javitt, Director, Program in Cognitive, Neuroscience and Schizophrenia, Nathan Kline Institute, 140 Old Orangeburg Road, Orangeburg, NY 10962, USA, Tel: + I 845398 6534, Fax: + I 845398 6545, E-mail: Javitt@nki.rfmh.org

Received 16 April 2003; revised 08 August 2003; accepted 26 August 2003

Online publication: 27 August 2003 at http://www.acnp.org/citations/ NPP08270303।63/default.pdf
Further, in early studies, behavioral effects of PCP were found to be most severe in patients with postencephalitic Parkinson's disease, suggesting critical interactions with brain dopaminergic systems (Meyer et al, 1959).

A recent finding in schizophrenia research has been the demonstration that patients show increased dopaminergic sensitivity to amphetamine challenge. This finding has been replicated in several cohorts using in vivo PET and SPECT imaging (Abi-Dargham et al, 1998; Breier et al, 1998, 1997; Kegeles et al, 1999; Laruelle et al, 1998, 1999, 1996, 1995, 1997a,b). Similar abnormalities are observed in humans following ketamine administration (Kegeles et al, 2000), and in rodents following acute (Balla et al, 2003; Miller and Abercrombie, 1996) or chronic (Balla et al, 2001b, 2003) NMDA antagonist administration.

NMDA receptors are modulated by amino acids, including glycine and D-serine, which bind to the glycine modulatory site of the NMDA complex. Both glycine (Javitt et al, 1999; Toth and Lajtha, 1986) and D-serine (Contreras, 1990; Nilsson et al, 1997) have been shown to reverse the behavioral effects of PCP in rodents following acute administration, indicating the in vivo relevance of the interaction. The effects of these agents during long-term administration, however, have not been evaluated. The use of D-serine in rodents is contraindicated because of nephrotoxicity (Carone and Ganote, 1975). In contrast, glycine is well tolerated in rodents for up to 5 months at 
doses that produce serum levels similar to those observed during clinical trials in schizophrenia (Shoham et al, 2001). The present study, therefore, evaluates the effects of longterm glycine treatment on neurochemical alterations induced by chronic PCP administration.

Occupancy of the glycine site is governed by a glycine (GlyT1) transporter that maintains low, subsaturating glycine levels in the immediate vicinity of NMDA receptors. Recently developed glycine transport inhibitors, such as glycyldodecylamide (GDA) (Javitt et al, 1999; Javitt and Frusciante, 1997) or N[3-(4"-fluorophenyl)-3-(4"-phenylphenoxy)propyl]sarcosine (NFPS) (Atkinson et al, 2001; Herdon et al, 2001), increase brain glycine levels in vivo (Atkinson et al, 2001) and potentiate NMDA receptormediated neurotransmission in vitro (Bergeron et al, 1998). As yet, however, few animal models have been published that show sensitivity to effects of these agents. The present study evaluates the degree to which PCP-induced enhancement of amphetamine-induced DA release in brain may be used to detect the effects of indirect, as well as direct, agonists of the NMDA-associated glycine-binding site.

\section{MATERIALS AND METHODS}

\section{Animals}

Studies were carried out in accordance with the Guide for the Care and Use of Laboratory Animals as adopted and promulgated by the National Institutes of Health. Male Sprague-Dawley rats (150-200 g) were bred in-house. Animals were maintained under a 10/14 h dark/light cycle, and were allowed food and water ad libitum during the microdialysis procedure and during the night-time locomotor activity measurements. Food was withdrawn during amphetamine challenge procedures. Three to nine animals were used per group.

\section{PCP Administration}

PCP hydrochloride (obtained from the National Institute of Drug Abuse) was dissolved in sterile physiological saline and administered via an osmotic pump (ALZA Corporation, model 2ML4) implanted under the skin. For 3-month administration, minipumps were replaced monthly to maintain appropriate serum levels. Saline-filled pumps were used in control animals. The pumps were filled based on the animal weight at the start of the experiment to deliver indicated PCP doses. The implantation was carried out under anesthesia with ketamine hydrochloride and acepromazine maleate $1: 1 \mathrm{mixture}(1 \mu \mathrm{l} / \mathrm{g} \mathrm{i} . \mathrm{m}$.$) .$

\section{Microdialysis}

Microdialysis was performed following either 14 days or 3 months of PCP administration, as indicated. Animals were still receiving PCP at the time of microdialysis. Animals were anesthetized with chloral hydrate $(400 \mathrm{mg} / \mathrm{kg}$ i.p.) and mounted in a stereotaxic frame (David Kopf Instrument). A CMA 10 guide cannula (Carnegie Medicine) was implanted into the left dorsomedial striatum and/or right prefrontal cortex. The implantation coordinates for the striatum (AP: +1.00 , L: 2.5, V: 4.00) and prefrontal cortex PFC (AP: + 4.1,
$\mathrm{L}:+1.0, \mathrm{~V}:-1.2,20 \%$ angle) were determined relative to bregma (Paxinos and Watson, 1998). Cannulae were cemented to the skull using dental acrylic with embedded stainless-steel bone screws.

During the $48 \mathrm{~h}$ following surgery, CMA 10 probes $(0.5 \mathrm{~mm} \times 2.0 \mathrm{~mm}$ or $4.0 \mathrm{~mm}$ membrane length with a molecular cutoff $20000 \mathrm{Da}$ ) were inserted into the guide cannulae. The estimated recovery rate was $18-20 \%$. Probes were continuously perfused using a syringe pump CMA/100 (Carnegie Medicine) at a flow rate of $1.0 \mu \mathrm{l} / \mathrm{min}$ with an $\mathrm{Mg}^{2+}$-free Ringer solution containing $\mathrm{NaCl} 147 \mathrm{mM}$; KCl $4 \mathrm{mM} ; \mathrm{CaCl}_{2} 1.2 \mathrm{mM}$ (degassed). A period of $2 \mathrm{~h}$ was allowed to establish the basal level of the extracellular catecholamines. Then 30-min dialysate samples were collected with a fraction collector (Bioanalytical Systems). After three baseline samples, the rats were challenged with amphetamine sulfate (RBI), which was dissolved in physiological saline and given subcutaneously at a dose of $1 \mathrm{mg} / \mathrm{kg}$.

Following completion of the experiment, animals were anesthetized with ketamine hydrochloride and acepromazine maleate $1: 1$ mixture $(1 \mu \mathrm{l} / \mathrm{g}$ i.m.). Blood samples were obtained via cardiac puncture, and plasma separated for PCP analysis. The rat brain was fixed first with $100 \mathrm{ml}$ of $0.9 \%$ saline in $0.1 \mathrm{M}$ phosphate, $\mathrm{pH}=7.4$, and then with $300 \mathrm{ml}$ of ice-cold $4 \%$ paraformaldehyde in $0.1 \mathrm{M}$ phosphate, $\mathrm{pH}=7.4$. The brains were cryoprotected in $30 \%$ sucrose in $0.1 \mathrm{M}$ phosphate. The placement of the probes was determined histologically.

\section{Dopamine Level Determinations}

Dopamine levels were determined by high-pressure liquid chromatography with electrochemical detection (HPLC-EC) (BAS-480 system). The dialysate samples $(30 \mu \mathrm{l})$ - collected in $0.1 \mathrm{~N}$ perchloric acid-were injected by autosampler (BAS Sample Sentinel) onto a microbore $\mathrm{C}_{18} 100 \times 2 \mathrm{~mm}^{2}$ column. The sample was eluted with filtered, degassed mobile phase $\left(\mathrm{NaH}_{2} \mathrm{PO}_{4} 25 \mathrm{mM}\right.$; sodium citrate $50 \mathrm{mM}$; disodium-EDTA $27 \mu \mathrm{M}$; diethylamine- $\mathrm{HCl} 10 \mathrm{mM}$; 1-octanesulfonic acid, sodium salt; methanol $3 \% \mathrm{v} / \mathrm{v}$; dimethylacetamide $2.1 \% \mathrm{v} / \mathrm{v} ; \mathrm{pH}=3.5$ ) at a flow rate of $0.4 \mathrm{ml} / \mathrm{min}$, yielding a retention time of $6.0 \mathrm{~min}$. Classic glassy carbon electrodes (BAS) $v s$ the $\mathrm{Ag} / \mathrm{AgCl}$ reference electrode at $0.60 \mathrm{~V}$ and sensitivity levels of $0.5 \mathrm{nA}$ were used for dopamine detection.

Data were acquired on an IBM-compatible PC using BAS5 interface. Standard curves were constructed using 7 pts between 0.625 and $80 \mathrm{pg} / 10 \mu \mathrm{l}$ for dopamine. Correlation coefficients $(r)$ of $>0.98$ were obtained for all curves. The working standard solutions were stored at $-80^{\circ} \mathrm{C}$ and $10 \mu \mathrm{l}$ of the standard solution was injected between biological samples.

\section{Data Analysis}

Primary dependent measures consisted of dopamine levels prior to and following amphetamine administration. Data were analyzed using repeated measures ANOVA with Geisser-Greenhouse correction, with within-subject measure of time following amphetamine injection (ie fraction or observation number) and between-subject factor of drug (PCP or saline). Significant main or interaction effects were 
followed up by a between-group post hoc $t$-test. Two-tailed statistics with an $\alpha$ level of significance of $p<0.05$ were used throughout. Data in the text are mean \pm SEM.

\section{RESULTS}

\section{3-Month Treatment Study}

An initial experiment evaluated the effects of glycine on PCP-induced dopaminergic hyper-reactivity during longterm PCP administration, to mimic the likely effects of prolonged clinical treatment with glycine in humans. This was considered the longest time over which rats could technically be maintained on PCP using osmotic minipumps. Rats were treated for 3 months with PCP $(5 \mathrm{mg} / \mathrm{kg} /$ day) or saline with or without concurrent glycine administration. Glycine was administered orally via an enriched diet ( $8 \%$ glycine by weight). Serum PCP levels obtained at the time of killing, $69.3 \pm 7.0 \mathrm{ng} / \mathrm{ml}$, were within the range associated with PCP psychosis in humans (Javitt and Zukin, $1991)$ and were not significantly different between glycinetreated and control animals $(p>0.2)$.

Glycine treatment led to a significant, two-fold increase in serum levels of glycine from $221 \pm 21$ to $480 \pm 97 \mu \mathrm{M}$ $(t=2.73, p<0.02)$ and a 1.5 -fold increase in serine levels from $167 \pm 10$ to $238 \pm 21 \mu \mathrm{M}(t=3.25, p<0.01)$. Although significantly elevated $v s$ control, these levels are somewhat lower than those achieved during clinical treatment with glycine (Heresco-Levy et al, 1999; Javitt et al, 2001; Leiderman et al, 1996). In order to verify that increased serum levels were associated with increased brain concentrations, amino acid levels were determined from preamphetamine microdialysate samples as well. As in serum, microdialysate glycine levels were increased approximately two-fold in glycine-treated $v s$ control animals $(p<0.05)$. A 1.4 -fold increase was observed for microdialysate serine levels, but the degree of between-group difference did not reach statistical significance (Figure 1). Glutamate, aspartate, and glutamine levels were unchanged.

A 3-month treatment with PCP led to a significant 1.5fold increase in amphetamine-induced PFC dopamine

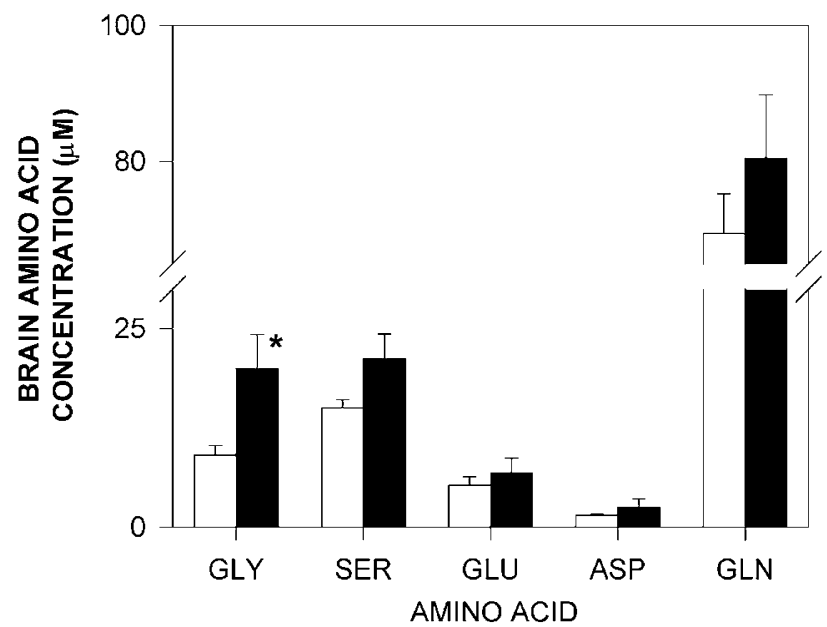

Figure I Microdialysis glycine levels in animals receiving regular (open bars, $n=11$ ) or a high-glycine ( $8 \%$ by weight) diet (solid bars, $n=13$ ). $* p<0.05$ glycine vs control. release vs control animals (Figure 2), as reflected in a significant group $(\mathrm{PCP} /$ control $) \times$ time interaction during the $0-210 \mathrm{~min}$ post-amphetamine treatment interval $\left(\mathrm{F}_{9,54}=4.4, p=0.006\right)$. In contrast, in animals receiving a glycine-enriched $(8 \%$ by weight $)$ diet, no PCP $\times$ time interaction was observed $\left(\mathrm{F}_{9,45}=0.1, p=0.9\right)$, although the main and interactive effects of glycine were not significant.

In control animals, the effects were most pronounced 150-210 min following amphetamine administration. A post hoc analysis was therefore conducted over this period alone. Over this time period, significant glycine $\times$ PCP $\left(\mathrm{F}_{1,12}=5.2\right.$, $p=0.04)$ and glycine $\times \mathrm{PCP} \times$ time $\left(\mathrm{F}_{2,24}=4.7, p=0.02\right)$ interactions were observed.

\section{2-Week, 16\% Glycine Diet}

As the glycine levels obtained during the 3-month study were somewhat below those obtained during clinical trials, a second study investigated the effects of a higher glycine dose $(16 \%$ by diet) for 2 weeks. Owing to the shorter treatment duration, a higher dose of PCP was used $(15 \mathrm{mg} /$ $\mathrm{kg} /$ day) for this study. The mean PCP levels among treated animals were $85.4 \pm 6.6 \mathrm{ng} / \mathrm{ml}$, with no significant difference between animals receiving regular $v s$ high-glycine diet. Serum glycine levels in rats receiving $16 \%$ glycine diet, $1236.0 \pm 253.4 \mathrm{nmol} / \mathrm{ml}$, were increased five-fold over levels in rats receiving a regular diet, $(238.4 \pm 50.7 \mathrm{nmol} / \mathrm{ml}$, $t=3.93, p<0.001)$ and within the range obtained during clinical studies with glycine (Heresco-Levy et al, 1999; Javitt et al, 2001; Leiderman et al, 1996).

For this study, dopamine levels were measured in both the frontal cortex and striatum (Figure 3). In animals receiving a regular diet (left panels), subchronic PCP treatment led to a significant increase in amphetaminestimulated DA release in both the PFC and striatum, as reflected in the significant $\mathrm{PCP} \times$ time effects $(\mathrm{FC}$ : $\mathrm{F}_{9,252}=6.9, p<0.001 ;$ STR: $\left.\mathrm{F}_{9,153}=5.8, p<0.001\right)$. These effects were prevented in animals receiving a high-glycine ( $16 \%$ by weight) diet, as reflected in the absence of significant $\mathrm{PCP} \times$ time effects $\left(\mathrm{F}_{9,153}=1.3, p>0.2\right.$; STR: $\left.\mathrm{F}_{9,126}=0.2, p>0.9\right)$.

In this data set, PCP treatment led to significant potentiation of amphetamine-stimulated dopamine release throughout the 30-210 min period in both the PFC $\left(\mathrm{F}_{1,43}=13.5, \quad p=0.001\right)$ and striatum $\left(\mathrm{F}_{1,33}=4.66\right.$, $p<0.04)$. This effect was reversed by glycine treatment as indicated by a significant glycine $\times$ PCP interaction in both

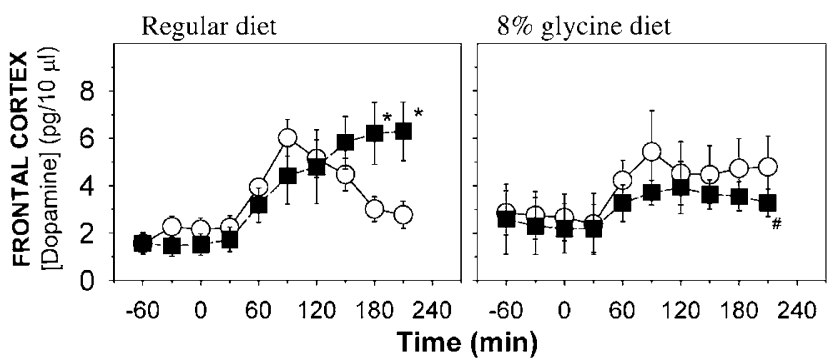

Figure 2 Effect of GLY on AMPH-induced DA release in PFC in animals treated with $5 \mathrm{mg} / \mathrm{kg} /$ day PCP for 12 weeks (filled squares) or salinetreated controls (open circles). $n=4-6$ per group. ${ }^{*} p<0.05$ PCP vs control, \#p<0.05 PCP + high-glycine vs PCP + regular diet. 


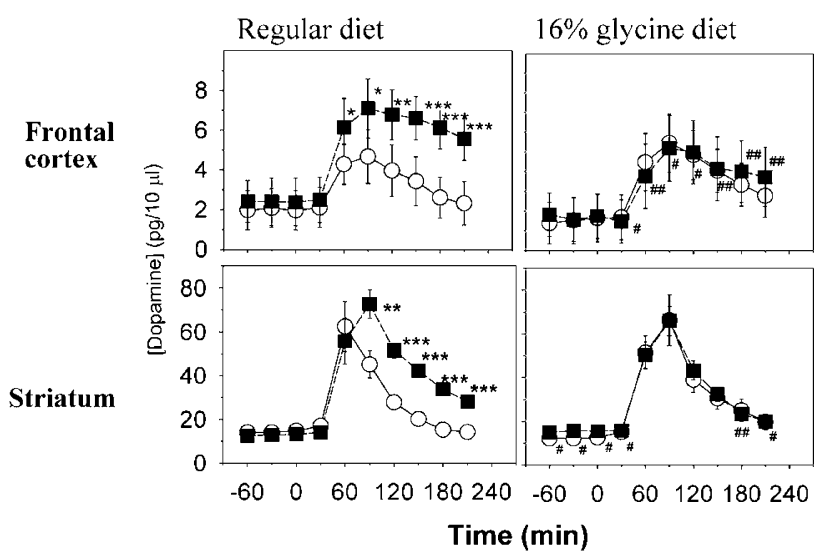

Figure 3 Effect of glycine on amphetamine-induced DA release in PFC (top) and striatum (bottom) in animals treated with $15 \mathrm{mg} / \mathrm{kg} /$ day PCP for 2 weeks (filled circles) or saline-treated controls (open circles). $n=7-20$ per group. $* p<0.05$ vs control, $* * * 0.01$, $* * * * * 0.001$; $\# p<0.05$ $\mathrm{PCP}+$ high-glycine vs $\mathrm{PCP}+$ regular diet, $\# \# p<0.01$.

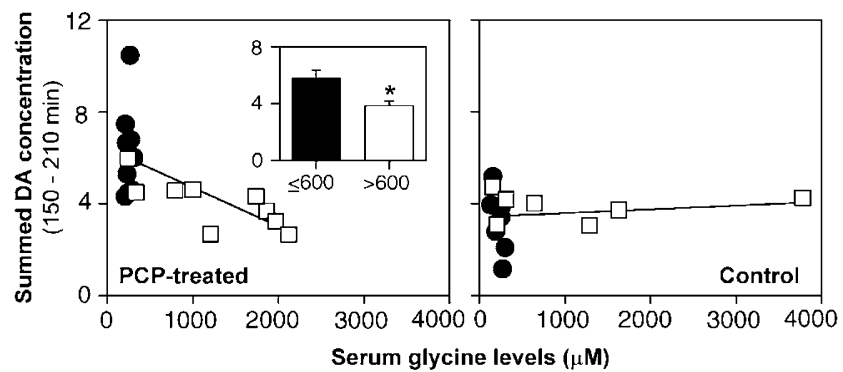

Figure 4 Relationship between serum glycine levels and PFC DA levels during the 150-210 min post-amphetamine-treatment time period in animals receiving PCP (left) and controls (right). Filled symbols indicate animals receiving a regular diet. Open symbols indicate animals receiving a high-glycine diet. Inset Bar chart showing the mean (SEM) PFC DA levels during the $150-210$ min period for PCP-treated animals with serum glycine levels $\leqslant 600 \mu M$ (filled bar, $n=12$ ) vs animals with the serum glycine levels $>600 \mu$ M (open bar, $n=6$ ). Regardless of diet, animals with serum glycine levels $\leqslant 600 \mu \mathrm{M}$ showed significantly lower levels of amphetamine-induced DA release than animals with serum glycine levels $>600 \mu \mathrm{M}$. $* t=2.91$, $p=0.01 \leqslant 600 \mu \mathrm{M}$ vs $>600 \mu \mathrm{M}$.

brain regions (PFC: $\mathrm{F}_{1,43}=6.58, p<0.02$; STR: $\mathrm{F}_{1,33}=4.93$, $p<0.04)$. For PCP-treated animals, but not controls (Figure 4), there was a significant negative correlation between serum glycine levels and potentiated amphetamineinduced DA release during the $150-210 \mathrm{~min}$ period $(r=-0.52, p<0.03)$, such that animals with serum glycine levels $>600 \mu \mathrm{M}$ showed significantly lower levels of amphetamine-induced dopamine release than those with levels $<600 \mu \mathrm{M}(t=2.91, p=0.01)$.

\section{Glycine Transport Inhibitors}

A final series of experiments evaluated the effects of the prototype glycine transport inhibitor NFPS. Owing to limited information concerning its brain penetration, NFPS was administered both intracerebroventricularly (i.c.v.) and systemically in separate studies. For i.c.v. studies, NFPS was administered via an osmotic minipump using a brain perfusion cannula inserted into the lateral ventricle. A dose

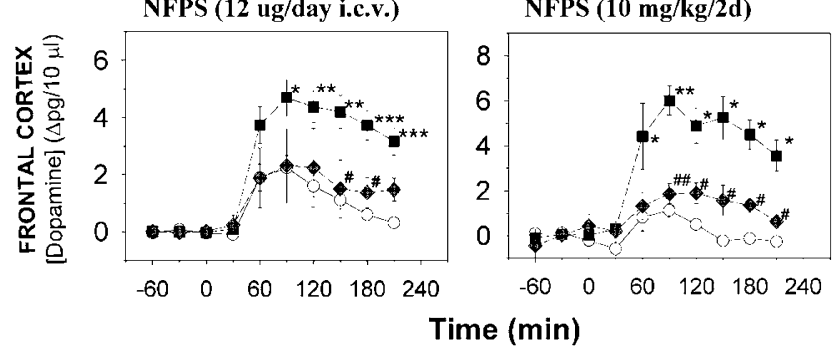

Figure 5 Effect of NFPS on amphetamine-induced DA release following i.c.v (left) or systemic (right) administration. Left panel: Amphetamineinduced DA release over basal ( -90 to $0 \mathrm{~min}$ ) in animals receiving NFPS for 2 weeks along with $15 \mathrm{mg} / \mathrm{kg} /$ day PCP (shaded circles) vs those receiving saline (open circles) or PCP alone (filled squares) $* p<0.05$ PCP vs saline; *** $<0.01 ; \# p<0.05$ PCP + NFPS vs PCP alone. Right panel: amphetamine-induced DA release over the basal level was significantly lower in animals receiving systemic NFPS for 3 days with (shaded diamonds) or without $20 \mathrm{mg} / \mathrm{kg} /$ day PCP (open circles) vs those receiving PCP alone (filled squares). ${ }^{*} p<0.05$ PCP vs saline; $* * * 0.01$, **** $p<0.00$ I; \#p $<0.05$ PCP + NFPS vs PCP alone, \#\#p<0.01

of $12 \mu \mathrm{g} /$ day was used, representing the maximum dosage that could be achieved using this delivery system. For systemic studies, NFPS was administered at a dose of $10 \mathrm{mg} /$ $\mathrm{kg}$ i.p. every other day $(10 \mathrm{mg} / \mathrm{kg} / 2$ day). This dose is reported to induce a two-fold increase in brain glycine concentrations (Atkinson et al, 2001). A 3-day treatment regimen was used.

The amphetamine-induced DA release over basal was significantly lower in animals receiving NFPS for 2 weeks along with $15 \mathrm{mg} / \mathrm{kg} /$ day PCP $v$ s those receiving PCP alone $\left(\mathrm{F}_{9,162}=2.2, p<0.03\right)$, but not significantly different than in animals receiving saline treatment alone $\left(\mathrm{F}_{9,108}=0.6\right.$, $p>0.8)$. Animals treated with NFPS systemically $\left(\mathrm{F}_{9,45}=5.5, p<0.001\right)$ also showed significantly reduced amphetamine-induced dopamine release relative to animals that received PCP alone. The differences between animals treated with PCP and those treated with NFPS along with PCP were significant throughout the $90-210$ min interval (Figure 5).

\section{DISCUSSION}

NMDA antagonists induce dopaminergic hyperactivity similar to that observed in schizophrenia in both human (Kegeles et al, 2000) and rodent (Balla et al, 2001b, 2003; Miller and Abercrombie, 1996) studies. In schizophrenia, treatment with NMDA co-agonists such as glycine, D-serine, and D-cycloserine produce significant amelioration of treatment-refractory symptoms, including improvement in both negative and positive symptoms (Javitt, 2002). Glycine effects are observed at serum levels of $>600 \mu \mathrm{M}$ (HerescoLevy et al, 1999; Leiderman et al, 1996). The present study demonstrates that glycine, at similar serum levels, reverses PCP-induced dysregulation of dopamine release in both the PFC and striatum, supporting the concepts first that it is effective in potentiating brain NMDA receptor-mediated neurotransmission and, second, that potentiation of NMDA receptor-mediated neurotransmission may be beneficial in schizophrenia. 
The present results can be interpreted on both a neurochemical and clinical level. On the neurochemical level, these results are consistent with other studies showing the regulation of frontal and striatal DA systems by NMDA receptors. For example, Svensson (2000) has demonstrated that NMDA antagonists induce alteration in the firing pattern of neurons in the ventral tegmental area projecting to the PFC. Similarly, mice lacking the NR1 subunit show dysregulated dopaminergic systems (Miyamoto et al, 2001). We have previously observed that systemic PCP does not potentiate DA release induced by local amphetamine administration (Balla et al, 2001a), suggesting circuit level or other interactions. Hippocampal glutamatergic afferents may also regulate firing of midbrain DA neurons via both NMDA and non-NMDA afferents (Floresco et al, 2001). Thus, the critical sites of interaction in the present study may not be within the PFC or striatum, but may be within regions such as the ventral tegmental area and substantia nigra that project to these regions. Following single-dose administration, NMDA antagonists such as PCP or MK-801 stimulate DA release for 1-2 h (Javitt et al, 1999). In the present study, no sustained elevation in the basal DA levels was observed following long-term administration, suggesting that tolerance develops to this effect during chronic continuous administration.

On a clinical level, the present results may help explain the beneficial effects of NMDA agonists on symptoms of schizophrenia. Initial studies of NMDA agonists focused on the effect of these agents on persistent negative symptoms (Javitt, 2002). More recent studies, however, have documented the effects of these agents even on persistent positive symptoms in patients receiving typical or atypical antipsychotic treatment (Heresco-Levy et al, 2003; Tsai et al, 1998). Excess dopamine release in striatum has been shown to be associated with increased positive symptoms in amphetamine-challenged schizophrenic patients (Laruelle et $a l, 1996)$. To the extent that dopaminergic dysregulation in schizophrenia is due to underlying NMDA dysfunction, the ability of NMDA agonists to decrease amphetaminestimulated DA release is consistent with the clinical therapeutic effect of these agents. In the present study, glycine was administered along with PCP throughout the study and prevented PCP effects. Future studies will be needed to determine the degree to which glycine supplementation added during the course of PCP treatment can reverse already established dopaminergic hyper-reactivity.

In schizophrenia, negative symptoms are thought to reflect functional hypodopaminergia, especially in the prefrontal cortex (Davis et al, 1991; Moore et al, 1999). However, as yet no studies have demonstrated reduced dopamine levels. In the present study, no change in baseline dopamine levels were observed in the prefrontal cortex. This finding is consistent with observations in both rats (Jentsch et al, 1998) and monkeys (Jentsch et al, 1997) that tissue dopamine levels remain unchanged following chronic treatment with NMDA antagonists, such as ketamine, PCP, or MK-801, although turnover rates (determined by metabolite:dopamine ratios) increase. The present findings argue against disturbances in absolute extracellular dopamine levels in schizophrenia, although not against disturbances in dopamine turnover. Since NMDA and D1 receptors show mutual facilitatory interactions (eg Chen and Yang, 2002; Scott et al, 2002; Wang and O'Donnell, 2001), disturbances in dopaminergic neurotransmission may occur independent of changes in extracellular dopamine levels.

The finding of exaggerated PFC response to amphetamine challenge in PCP-treated animals is also consistent with recent observations in schizophrenia. The majority of amphetamine challenge studies in schizophrenia have been conducted primarily with neuroleptic-treated, stabilized patients. In such patients, amphetamine typically produces small, but consistent improvement in cognitive functioning (eg Daniel et al, 1991; Goldberg et al, 1991). In contrast, a recent study investigated the effects of the indirect dopamine agonist methylphenidate in both acute and stabilized patients using the Word Production Test (Szeszko et al, 1999), a putative marker of prefrontal functioning (Yurgelun-Todd et al, 1996). Acute-phase patients showed significantly lower response rates than stabilized patients. Further, both groups showed deterioration of performance during methylphenidate challenge, along with increasing conceptual disorganization. By contrast, methylphenidate typically improves the prefrontal performance to novel tasks in normal volunteers (Elliott et al, 1997; Mehta et al, 2000), supporting the concept that patients show increased susceptibility to the disorganizing effects of prefrontal hyperdopaminergia following psychostimulant administration.

NMDA antagonists induce working memory dysfunction similar to those observed in schizophrenia (Adler et al, 1998; Krystal et al, 2000, 1994; Umbricht et al, 2000). Further NMDA agonists decrease conceptual disorganization (Javitt, 2002), and potentially improve working memory performance in schizophrenia (Tsai et al, 1998). The present findings are thus consistent with a model in which persistent NMDA dysfunction produces a tonic level of working memory dysfunction, which is prone to further disruption by hyperdopaminergia induced by either acute decompensation or psychopharmacological agents.

Aside from demonstrating the effectiveness of glycine and glycine transport inhibitors against PCP-induced augmentation of amphetamine-stimulated dopamine release, the present study provides the first demonstration that administration of clinically relevant glycine doses in animals leads to significant elevation of brain glycine levels. The administration of an $8 \%$ glycine diet to rodents, which led to a two-fold increase in serum glycine levels, also led to a two-fold increase in microdialysate glycine levels and a 1.4fold increase in microdialysate serine levels. As glycine enters the brain by passive diffusion across the blood-brain barrier, serum and brain glycine levels would be expected to equilibrate over time. In acute studies in humans, an 8-fold increase in serum glycine levels produced a two-fold increase in CSF levels $1.5 \mathrm{~h}$ after administration (D'Souza et al, 2000). Although the glycine elevation observed in that study was significant, the results of the present study suggest that the degree of elevation of brain glycine levels $v s$ serum during chronic treatment may be substantially higher than has been observed in acute studies. Glycine was welltolerated in rats even during 3-month administration, as has been noted previously (Shoham et al, 1999). The present study suggests that administering $8-16 \%$ by weight glycineenriched diet may be an effective method for producing 
serum glycine levels similar to those observed during clinical studies in humans.

The mean serum PCP level in this study is similar to that observed in other studies using chronic PCP administration (eg Proksch et al, 2000). Notably, because of the slow infusion rate used, peak serum concentrations were substantially below those encountered during i.v. (Proksch et al, 2000) or i.p. (Bailey and Guba, 1980) administration of even relatively low doses of PCP (eg $1-3 \mathrm{mg} / \mathrm{kg}$ ). NMDA antagonists, such as PCP, may induce neurodegeneration of structures involved in this study (ie PFC, striatum) following repeated, acute high-dose administration, for example, $20 \mathrm{mg} / \mathrm{kg}$ i.v. given once per day for 5 days. Neurotoxic effects, moreover, are significantly more pronounced in female, than male, rats (Johnson et al, 1998). Previous studies with male rats using doses similar to those in the present study (eg $10 \mathrm{mg} / \mathrm{kg} /$ day) have failed to observe significant effects of PCP on behavioral sensitization (Johnson et al, 1998) or PCP receptor binding (Burke et al, 1995).

In summary, the present treatment approaches for schizophrenia are based primarily upon dopaminergic models of the disorder. Although many patients respond well to antidopaminergic therapies, the majority of patients show persistent symptomatology despite treatment with either typical or atypical antipsychotic agents. The present study supports clinical research demonstrating significant improvement in negative, positive, and cognitive symptoms of schizophrenia with NMDA agonists including glycine, Dserine, and D-cycloserine (Goff et al, 1999; Heresco-Levy et al, 1999; Javitt et al, 2001, 1994; Shoham et al, 2001; Tsai et al, 1998). A prior study with the first available glycine transport inhibitor, GDA, demonstrated its ability to reverse PCP-induced hyperactivity in rodents (Javitt et al, 1999; Javitt and Frusciante, 1997). This study is the first to examine the in vivo effects of a more selective glycine transport inhibitor, NFPS. The finding that glycine transport inhibitors exert in vivo effects similar to glycine or other NMDA agonists supports the hypothesis that these agents may be useful in the treatment of persistent symptoms of schizophrenia.

\section{ACKNOWLEDGEMENTS}

This paper was supported in part by USPHS Grants R01 DA03383 and K02 MH01439 to DC, and the Burroughs Wellcome Fund. NFPS was provided for research use by NPS-Pharmaceuticals (Mississauga, Ontario, Canada).

\section{REFERENCES}

Abi-Dargham A, Gil R, Krystal J, Baldwin RM, Seibyl JP, Bowers M et al (1998). Increased striatal dopamine transmission in schizophrenia: confirmation in a second cohort. Am J Psychiatry 155: 761-767.

Adler CM, Goldberg TE, Malhotra AK, Pickar D, Breier A (1998). Effects of ketamine on thought disorder, working memory, and semantic memory in healthy volunteers. Biol Psychiatry 43: 811-816.

Atkinson BN, Bell SC, De Vivo M, Kowalski LR, Lechner SM, Ognyanov VI et al (2001). ALX 5407: a potent, selective inhibitor of the hGlyT1 glycine transporter. Mol Pharmacol 60: 1414-1420.
Bailey DN, Guba JJ (1980). Measurement of phencyclidine in saliva. J Anal Toxicol 4: 311-313.

Balla A, Hashim A, Burch S, Javitt DC, Lajtha A, Sershen H (2001a). Phencyclidine-induced dysregulation of dopamine response to amphetamine in prefrontal cortex and striatum. Neurochem Res 26: $1001-1006$.

Balla A, Koneru R, Smiley J, Sershen H, Javitt DC (2001b). Continuous phencyclidine treatment induces schizophrenia-like hyperreactivity of striatal dopamine release. Neuropsychopharmacology 25: 157-164.

Balla A, Sershen H, Serra M, Koneru R, Javitt DC (2003). Subchronic continuous phencyclidine administration potentiates amphetamine-induced frontal cortex dopamine release. Neuropsychopharmacology 28: 34-44.

Bergeron R, Meyer TM, Coyle JT, Greene RW (1998). Modulation of $N$-methyl-D-aspartate receptor function by glycine transport. Proc Natl Acad Sci USA 95: 15730-15734.

Breier A, Adler CM, Weisenfeld N, Su TP, Elman I, Picken L et al (1998). Effects of NMDA antagonism on striatal dopamine release in healthy subjects: application of a novel PET approach. Synapse 29: 142-147.

Breier A, Su TP, Saunders R, Carson RE, Kolachana BS, de Bartolomeis A et al (1997). Schizophrenia is associated with elevated amphetamine-induced synaptic dopamine concentrations: evidence from a novel positron emission tomography method. Proc Natl Acad Sci USA 94: 2569-2574.

Burke TF, Buzzard S, Wessinger WD (1995). [ $\left.{ }^{3} \mathrm{H}\right]$ MK-801 binding to well-washed rat brain membranes following cessation of chronic phencyclidine treatment. Pharmacol Biochem Behav 51: 435-438.

Carone FA, Ganote CE (1975). D-Serine nephrotoxicity. The nature of proteinuria, glucosuria, and aminoaciduria in acute tubular necrosis. Arch Pathol 99: 658-662.

Chen L, Yang CR (2002). Interaction of dopamine D1 and NMDA receptors mediates acute clozapine potentiation of glutamate EPSPs in rat prefrontal cortex. J Neurophysiol 87: 2324-2336.

Contreras PC (1990). D-Serine antagonized phencyclidine- and MK-801-induced stereotyped behavior and ataxia. Neuropharmacology 29: 291-293.

Coyle JT (1996). The glutamatergic dysfunction hypothesis for schizophrenia. Harvard Rev Psychiatry 3: 241-253.

Daniel DG, Weinberger DR, Jones DW, Zigun JR, Coppola R, Handel S et al (1991). The effect of amphetamine on regional cerebral blood flow during cognitive activation in schizophrenia. J Neurosci 11: 1907-1917.

Davis KL, Kahn RS, Ko GN, Davidson M (1991). Dopamine in schizophrenia: a review and reconceptualization. Am J Psychiatry 148: $1474-1486$.

D’Souza DC, Gil R, Cassello K, Morrissey K, Abi-Saab D, White J et al (2000). IV glycine and oral D-cycloserine effects on plasma and CSF amino acids in healthy humans. Biol Psychiatry 47: $450-462$.

Elliott R, Sahakian BJ, Matthews K, Bannerjea A, Rimmer J, Robbins TW (1997). Effects of methylphenidate on spatial working memory and planning in healthy young adults. Psychopharmacology (Berlin) 131: 196-206.

Floresco SB, Todd CL, Grace AA (2001). Glutamatergic afferents from the hippocampus to the nucleus accumbens regulate activity of ventral tegmental area dopamine neurons. J Neurosci 21: 4915-4922.

Goff DC, Tsai G, Levitt J, Amico E, Manoach D, Schoenfeld DA et al (1999). A placebo-controlled trial of D-cycloserine added to conventional neuroleptics in patients with schizophrenia. Arch Gen Psychiatry 56: 21-27.

Goldberg TE, Bigelow LB, Weinberger DR, Daniel DG, Kleinman JE (1991). Cognitive and behavioral effects of the coadministration of dextroamphetamine and haloperidol in schizophrenia. Am J Psychiatry 148: 78-84. 
Herdon HJ, Godfrey FM, Brown AM, Coulton S, Evans JR, Cairns WJ (2001). Pharmacological assessment of the role of the glycine transporter GlyT-1 in mediating high-affinity glycine uptake by rat cerebral cortex and cerebellum synaptosomes. Neuropharmacology 41: 88-96.

Heresco-Levy U, Javitt DC, Ermilov M, Lichtenberg P, Bar G (2003). High dose glycine added to olanzapine and risperidone for the treatment of schizophrenia. Biol Psychiatry, in press.

Heresco-Levy U, Javitt DC, Ermilov M, Mordel C, Silipo G, Lichtenstein M (1999). Efficacy of high-dose glycine in the treatment of enduring negative symptoms of schizophrenia. Arch Gen Psychiatry 56: 29-36.

Javitt DC (2002). Glycine modulators in schizophrenia. Curr Opin Investig Drugs 3: 1067-1072.

Javitt DC, Balla A, Sershen H, Lajtha A (1999). A.E. Bennett Research Award. Reversal of phencyclidine-induced effects by glycine and glycine transport inhibitors. Biol Psychiatry 45: 668-679.

Javitt DC, Frusciante M (1997). Glycyldodecylamide, a phencyclidine behavioral antagonist, blocks cortical glycine uptake: implications for schizophrenia and substance abuse. Psychopharmacol 129: 96-98.

Javitt DC, Jotkowitz A, Sircar R, Zukin SR (1987). Non-competitive regulation of phencyclidine/sigma-receptors by the $N$-methyl-Daspartate receptor antagonist D-(-)-2-amino-5-phosphonovaleric acid. Neurosci Lett 78: 193-198.

Javitt DC, Silipo G, Cienfuegos A, Shelley AM, Bark N, Park M et al (2001). Adjunctive high-dose glycine in the treatment of schizophrenia. Int J Neuropsychopharmacol 4: 385-392.

Javitt DC, Zukin SR (1990). The role of excitatory amino acids in neuropsychiatric illness. J Neuropsychiatry Clin Neurosci 2: 44-52.

Javitt DC, Zukin SR (1991). Recent advances in the phencyclidine model of schizophrenia. Am J Psychiatry 148: 1301-1308.

Javitt DC, Zylberman I, Zukin SR, Heresco-Levy U, Lindenmayer JP (1994). Amelioration of negative symptoms in schizophrenia by glycine. Am J Psychiatry 151: 1234-1236.

Jentsch JD, Redmond Jr DE, Elsworth JD, Taylor JR, Youngren KD, Roth RH (1997). Enduring cognitive deficits and cortical dopamine dysfunction in monkeys after long-term administration of phencyclidine. Science 277: 953-955.

Jentsch JD, Taylor JR, Elsworth JD, Redmond Jr DE, Roth RH (1999). Altered frontal cortical dopaminergic transmission in monkeys after subchronic phencyclidine exposure: involvement in frontostriatal cognitive deficits. Neuroscience 90: 823-832.

Jentsch JD, Taylor JR, Roth RH (1998). Subchronic phencyclidine administration increases mesolimbic dopaminergic system responsivity and augments stress- and psychostimulant-induced hyperlocomotion. Neuropsychopharmacology 19: 105-113.

Johnson KM, Phillips M, Wang C, Kevetter GA (1998). Chronic phencyclidine induces behavioral sensitization and apoptotic cell death in the olfactory and piriform cortex. J Neurosci Res 52: 709-722.

Kegeles LS, Abi-Dargham A, Zea-Ponce Y, Rodenhiser-Hill J, Mann JJ, Van Heertum RL et al (2000). Modulation of amphetamineinduced striatal dopamine release by ketamine in humans: implications for schizophrenia. Biol Psychiatry 48: 627-640.

Kegeles LS, Zea-Ponce Y, Abi-Dargham A, Rodenhiser J, Wang T, Weiss $\mathrm{R}$ et al (1999). Stability of [123I]IBZM SPECT measurement of amphetamine-induced striatal dopamine release in humans [In Process Citation]. Synapse 31: 302-308.

Krystal JH, Bennett A, Abi-Saab D, Belger A, Karper LP, D'Souza DC et al (2000). Dissociation of ketamine effects on rule acquisition and rule implementation: possible relevance to NMDA receptor contributions to executive cognitive functions. Biol Psychiatry 47: 137-143.

Krystal JH, Karper LP, Seibyl JP, Freeman GK, Delaney R, Bremner JD et al (1994). Subanesthetic effects of the noncompetitive
NMDA antagonist, ketamine, in humans. Psychotomimetic, perceptual, cognitive, and neuroendocrine responses. Arch Gen Psychiatry 51: 199-214.

Laruelle $M$ (1998). Imaging dopamine transmission in schizophrenia. A review and meta-analysis. Q J Nucl Med 42: 211-221.

Laruelle M, Abi-Dargham A, Gil R, Kegeles LS, Innis R (1999). Increased dopamine transmission in schizophrenia: relationship to illness phases. Biol Psychiatry 46: 56-72.

Laruelle M, Abi-Dargham A, van Dyck CH, Gil R, D'Souza CD, Erdos J et al (1996). Single photon emission computerized tomography imaging of amphetamine- induced dopamine release in drug-free schizophrenic subjects. Proc Natl Acad Sci USA 93: 9235-9240.

Laruelle M, Abi-Dargham A, van Dyck CH, Rosenblatt W, ZeaPonce Y, Zoghbi SS et al (1995). SPECT imaging of striatal dopamine release after amphetamine challenge. J Nucl Med 36: $1182-1190$.

Laruelle M, D'Souza CD, Baldwin RM, Abi-Dargham A, Kanes SJ, Fingado CL et al (1997a). Imaging D2 receptor occupancy by endogenous dopamine in humans. Neuropsychopharmacology 17: 162-174.

Laruelle M, Iyer RN, al-Tikriti MS, Zea-Ponce Y, Malison R, Zoghbi SS et al (1997b). Microdialysis and SPECT measurements of amphetamine-induced dopamine release in nonhuman primates. Synapse 25: 1-14.

Leiderman E, Zylberman I, Zukin SR, Cooper TB, Javitt DC (1996). Preliminary investigation of high-dose oral glycine on serum levels and negative symptoms in schizophrenia: an open-label trial. Biol Psychiatry 39: 213-215.

Mehta MA, Owen AM, Sahakian BJ, Mavaddat N, Pickard JD, Robbins TW (2000). Methylphenidate enhances working memory by modulating discrete frontal and parietal lobe regions in the human brain. J Neurosci 20: RC65.

Meyer JS, Greifenstein F, DeVault M (1959). A new drug causing symptoms of sensory deprivation. J Nerv Ment Dis 129: $54-61$.

Miller DW, Abercrombie ED (1996). Effects of MK-801 on spontaneous and amphetamine-stimulated dopamine release in striatum measured with in vivo microdialysis in awake rats. Brain Res Bull 40: 57-62.

Miyamoto Y, Yamada K, Noda Y, Mori H, Mishina M, Nabeshima $T$ (2001). Hyperfunction of dopaminergic and serotonergic neuronal systems in mice lacking the NMDA receptor epsilon1 subunit. J Neurosci 21: 750-757.

Moore H, West AR, Grace AA (1999). The regulation of forebrain dopamine transmission: relevance to the pathophysiology and psychopathology of schizophrenia. Biol Psychiatry 46: 40-55.

Newcomer JW, Farber NB, Jevtovic-Todorovic V, Selke G, Melson AK, Hershey T et al (1999). Ketamine-induced NMDA receptor hypofunction as a model of memory impairment and psychosis. Neuropsychopharmacology 20: 106-118.

Nilsson M, Carlsson A, Carlsson ML (1997). Glycine and D-Serine decrease MK-801-induced hyperactivity in mice. J Neural Transm 104: 1195-1205.

Paxinos G, Watson C (1998). The Rat Brain in Stereotaxic Coordinates. Academic Press: Sydney.

Proksch JW, Gentry WB, Owens SM (2000). The effect of rate of drug administration on the extent and time course of phencyclidine distribution in rat brain, testis, and serum. Drug Metab Dispos 28: 742-747.

Scott L, Kruse MS, Forssberg H, Brismar H, Greengard P, Aperia A (2002). Selective up-regulation of dopamine D1 receptors in dendritic spines by NMDA receptor activation. Proc Natl Acad Sci USA 99: 1661-1664.

Shoham S, Javitt DC, Heresco-Levy U (1999). High dose glycine nutrition affects glial cell morphology in rat hippocampus and cerebellum. Int J Neuropsychopharmacol 2: 35-40. 
Shoham S, Javitt DC, Heresco-Levy U (2001). Chronic high-dose glycine nutrition: effects on rat brain cell morphology. Biol Psychiatry 49: 876-885.

Svensson TH (2000). Dysfunctional brain dopamine systems induced by psychotomimetic NMDA-receptor antagonists and the effects of antipsychotic drugs. Brain Res Brain Res Rev 31: 320-329.

Szeszko PR, Bilder RM, Dunlop JA, Walder DJ, Lieberman JA (1999). Longitudinal assessment of methylphenidate effects on oral word production and symptoms in first-episode schizophrenia at acute and stabilized phases. Biol Psychiatry 45: 680-686.

Toth E, Lajtha A (1986). Antagonism of phencyclidineinduced hyperactivity by glycine in mice. Neurochem Res 11: 393-400.
Tsai G, Yang P, Chung LC, Lange N, Coyle JT (1998). D-Serine added to antipsychotics for the treatment of schizophrenia. Biol Psychiatry 44: 1081-1089.

Umbricht D, Schmid L, Koller R, Vollenweider FX, Hell D, Javitt DC (2000). Ketamine-induced deficits in auditory and visual context-dependent processing in healthy volunteers: implications for models of cognitive deficits in schizophrenia. Arch Gen Psychiatry 57: 1139-1147.

Wang J, O'Donnell P (2001). D(1) dopamine receptors potentiate NMDA-mediated excitability increase in layer $\mathrm{V}$ prefrontal cortical pyramidal neurons. Cereb Cortex 11: 452-462.

Yurgelun-Todd DA, Waternaux CM, Cohen BM, Gruber SA, English CD, Renshaw PF (1996). Functional magnetic resonance imaging of schizophrenic patients and comparison subjects during word production. Am J Psychiatry 153: 200-205. 